\title{
A formalin-inactivated immunogen against viral encephalopathy and retinopathy (VER) disease in European sea bass (Dicentrarchus labrax): immunological and protection effects
}

\author{
Noelia Nuñez-Ortiz ${ }^{1}$, Francesco Pascoli², Simona Picchietti ${ }^{1}$, Francesco Buonocore ${ }^{1}$, Chiara Bernini ${ }^{1}$,
} Marica Toson ${ }^{3}$, Giuseppe Scapigliati ${ }^{1 *}$ (1) and Anna Toffan ${ }^{2}$

\begin{abstract}
The European sea bass (Dicentrarchus labrax) is an important farmed fish species in the Mediterranean area, very sensitive to the infection by encephalopathy and retinopathy virus (VERV), or Betanodavirus, which causes massive mortalities. Effective vaccines to fight the pathology are not yet available and in this work we describe a promising intraperitoneal immunization route against VERV of sea bass juveniles. We performed intraperitoneal and immersion immunization trials with a VERV (isolate 283.2009 RGNNV) inactivated by formalin, $\beta$-propiolactone and heat treatment. Interestingly, the intraperitoneal immunization with formalin-inactivated VERv induced a significant antigenspecific IgM production, differently from other inactivation protocols. However, the same formalin-inactivated antigen resulted in very low IgM antibodies when administered by immersion. Following the intraperitoneal injection with formalin-inactivated virus, the quantitative expression of the antiviral MxA gene showed a modulation of transcripts in the gut after $48 \mathrm{~h}$ and on head kidney after $24 \mathrm{~h}$, whereas ISG12 gene was significantly up-regulated after $48 \mathrm{~h}$ on both tissues. In immersion immunization with formalin-inactivated VERV, a modulation of MxA and ISG12 genes after $24 \mathrm{~h}$ post-treatment was detected in the gills. An effective uptake of VERv particles in the gills was confirmed by immunohistochemistry using anti-VERv antibodies. Lastly, in challenge experiments using live VERv after intraperitoneal immunization with formalin-inactivated VERV, we observed a significant increase (81.9\%) in relative survival percentage with respect to non-immunized fish, whereas immersion immunization resulted in no protection. Our results suggest that intraperitoneal immunization with formalin-inactivated VERV could be a safe and effective strategy to fight Betanodavirus infection in European sea bass.
\end{abstract}

\section{Introduction}

Viral encephalopathy and retinopathy (VER), also known as viral nervous necrosis (VNN), is a severe infectious disease characterized by neuropathological changes and associated with high mortality in several fish species.

*Correspondence: scapigg@unitus.it

1 Department for Innovation in Biological, Agro-food and Forest Systems, University of Tuscia, Viterbo, Italy

Full list of author information is available at the end of the article
Viruses belonging to the Nodaviridae family, genus Betanodavirus, are non-enveloped single strand positive RNA virus characterized by an extremely high resistance to chemical and physical agents [1]. Betanodavirus is a highly pathogenic virus able to evade the host's protective systems and can either replicate and transmit progeny to other cells or remain in a latent condition [2]. Betanodavirus is one of the most significant viral pathogens of finfish and represents a bottleneck for development of mariculture in several countries $[3,4]$. 
Several experimental vaccines against VNN have been tested so far [5-7]. However, most of them have been tested on grouper (Epinephelus spp.), very likely the most important and valuable fish amongst the VER-susceptible species [8]. An inactivated VERv vaccine (RGNNV genotype) against VER of sevenband grouper (Epinephelus septemfasciatus) has been produced and marketed in Japan. Sea bass (Dicentrarchus labrax) is the second most farmed species in the Mediterranean Sea (FEAP 2005-2014) and also highly susceptible to VER. Notably, the VER introduction in the Mediterranean basin dates back to the early 90 s and was firstly detected in sea bass hatcheries [9]. All stages of sea bass are highly sensitive to Betanodavirus but mortality can vary depending on the fish age and water temperature [10]. Larval and juvenile stages are commonly the most affected, reaching mortalities up to $100 \%$. Infected larvae and juvenile stages often show flexing of the body, muscle tremors and abnormal swimming behaviour, which includes vertical positioning and spinning resulting from traumatic lesions [11]. Betanodavirus also causes hyperinflation of the swim bladder, with diseased fish present primarily at the surface. In adults, where the mortaly rate can reach 50-60\% $[10,12]$, the most common clinical sign is abnormal swimming.

Despite the huge losses to Mediterranean aquaculture, in particular to sea bass farms, very few vaccines have been tested in this species. Only few experimental products based on recombinant protein or synthetic peptides have been used by injecting intramuscularly juveniles sea bass of 20-66 g $[13,14]$. The use of a recombinant capsid protein has given interesting results but, at present, a vaccine against Betanodavirus for D. labrax is commercially not available.

The objectives of the present work were: (1) to investigate the best inactivation system for the production of immunogens, (2) to test the efficacy of the best inactivation method to protect experimentally, infected fish, and (3) to evaluate the immune response of immunized European sea bass. To achieve this we used two size-classes of fish, on the base of previous studies from our laboratory showing that intraperitoneal injection is inadvisable in fish with a mean weight lower than $5 \mathrm{~g}$, and that bath challenge is not applicable over that weight.

\section{Materials and methods}

\section{Fish}

Eight hundred and twenty (820) juvenile European sea bass (410 with an average weight of $2.10 \pm 0.25 \mathrm{~g}$ and 410 with an average weight of $6.30 \pm 0.45 \mathrm{~g}$ ) were transferred from a VER-free commercial farm (previously tested by PCR to be VERv-free, data not shown) to the experimental aquarium at the Istituto Zooprofilattico Sperimentale delle Venezie (IZSVe, Legnaro-PD, Italy). On arrival, forty fish were sampled in order to be checked for the most common pathogens (parasites, bacteria and viruses). Preliminary analyses confirmed that all the fish were pathogen-free. After this first phase, they were equally distributed in 9 different close system tanks according to their size (4 tanks with 80 fish of bigger size, and 5 tanks with 80 fish of smaller size), with $300 \mathrm{~L}$ of artificial salt water at $25 \%$ of salinity, at a temperature of $22 \pm 1{ }^{\circ} \mathrm{C}$, oxygen $6 \pm 0.5 \mathrm{ppm}$ and artificial photoperiod of $8 \mathrm{~h}$ of light and $16 \mathrm{~h}$ of darkness.

\section{Virus}

The virus was selected according to its degree of high pathogenicity for fish. In 2009, RGNNV 283.2009 was isolated from severely affected sea bass during an outbreak in a commercial farm in the northern Adriatic Sea. The virus had been previously used in the IZSVe experimental aquarium, showing a mortality rate of $>35 \%$ by immersion exposure in sea bass $[15,16]$. The isolate was propagated on E-11 cells (10 passages) [17], a clone of SSN-1 cell line [18], in $150 \mathrm{~cm}^{2}$ tissue culture flasks using L-15 medium (Leibovitz) (Sigma-Aldrich) without fetal calf serum. The collected virus was subjected to titration by endpoint dilutions assays. Titres were calculated according to the Spearman-Karber formula [19] and expressed as $\mathrm{TCID}_{50} / \mathrm{mL}$.

\section{Immunogens preparation}

The E-11 cell medium containing VERv was centrifuged at $2000 \mathrm{~g}$ for $10 \mathrm{~min}$ to remove cell debris, and then, the virus was inactivated with three different methods to prepare three different immunogens (titre $6.31 \times 10^{7}$ $\mathrm{TCID}_{50} / \mathrm{mL}$ ). Formalin inactivation was carried out by adding buffered formalin (Carlo Erba, Italy) at a final concentration of $10 \mu \mathrm{L} / \mathrm{mL}$ and left at room temperature $\left(22-25{ }^{\circ} \mathrm{C}\right.$ ) for 1 week. The $\beta$-propiolactone (BPL, Ferak, Berlin) inactivation was performed by adding $20 \mu \mathrm{L} / \mathrm{mL}$ of $\mathrm{BPL}$ for $3 \mathrm{~h}$ at $37{ }^{\circ} \mathrm{C}$. Inactivation by heat treatment was done in a heated bath at $70{ }^{\circ} \mathrm{C}$ for $1 \mathrm{~h}$. All immunogen preparations were checked after treatment using virological analyses according to a standard procedure [16], performing three sequential serial blind passages to ensure the complete inactivation of the pathogen. One batch of virus was kept untreated and used for a live virus immersion trial.

\section{Fish immunization and challenge}

After a period of acclimation of 10 days, fish were immunized as follows. Bigger fish (average weight of $6.30 \pm 0.45 \mathrm{~g}$ ) were sedated with $10 \mathrm{mg} / \mathrm{L}$ tricaine methasulfonate (MS-222) (Sigma-Aldrich) and then immunized by intraperitoneal injection (i.p.) of $0.1 \mathrm{~mL} /$ 
fish (using syringes with a 26-gauge needle) of the three different immunogens preparations described above (one per tank); whereas smaller fish (average weight of $2.10 \pm 0.25 \mathrm{~g}$ ) were immunized by immersion in a $30-\mathrm{L}$ water tank with aerator for 2 min with a final titre of $10^{6} \mathrm{TCID}_{50} / \mathrm{mL}$ of the same inactivated formulations. A new group was added and immersed with a suboptimal dose of live virus (approximately $10^{4} \mathrm{TCID}_{50} /$ $\mathrm{mL}$ ), following a previous protocol [20]. The controls for experimental groups were done by i.p. injection and immersion (mock-immunization) with 0.01 M PBS (Sigma-Aldrich). These controls acted as negative control for immunological assays and as positive control in the challenge. One tank was left untreated as negative control, in order to assess general viability during treatments and challenge. Thirty days post immunization, blood and brain samples were collected from fish $(n=10)$ from all groups.

According to the results from immunological analyses (see below), we focused our study on formalin-inactivated VERv groups, from which we performed real-time quantitative PCR (qPCR) to measure the transcription of antiviral genes. We then tested the survival rate in the same groups after challenge with live virus.

After 30 days post immunization (dpv), the formylated groups were challenged with RGNNV 283.2009 by immersion or intramuscular injection, according to the prior immunization route. As for immersion, each group of 50 fish was transferred to a 30-L water tank with aerator and infected for $4 \mathrm{~h}$ by adding $30 \mathrm{~mL}$ of virus solution (final titre $10^{6} \mathrm{TCID}_{50} / \mathrm{mL}$ ) to the water. For intramuscular injection, 50 fish were injected (after anesthesia) with $0.1 \mathrm{~mL}$ of virus solution (approximately $\left.6.3110^{6} \mathrm{TCID}_{50} / \mathrm{fish}\right)$. The "positive control" group, mock-immunized by i.p. and immersion respectively by using PBS $0.01 \mathrm{M}$, was infected by immersion or injected as explained before. The "negative control" group was either mock infected by immersion by adding minimum essential medium (MEM-10) without virus to the water, or injected with 0.1 MEM-10 rather than with the virus solution administered to the intramuscularly infected group.

Fish were then transferred back to the original tanks and kept at a temperature of $25 \pm 1{ }^{\circ} \mathrm{C}$, oxygen $6 \pm 0.5 \mathrm{ppm}$ and artificial photoperiod of $8 \mathrm{~h}$ of light and $16 \mathrm{~h}$ of darkness. Fish were checked twice a day and the dead ones were removed. Brain samples were collected individually from each dead fish and stored at $-80{ }^{\circ} \mathrm{C}$. The experiment ended on day 30 and the relative percent survival (RPS) calculated. All the remaining fish were euthanized by an overdose of MS-222, sampled and stored at $-80{ }^{\circ} \mathrm{C}$ until analyses.

\section{Immunological analyses}

The blood from juveniles sea bass was collected from the caudal vein of lethally anaesthetized fish (overdose of MS-222). Sera were obtained by centrifugation at $1000 \mathrm{~g}$ for $5 \mathrm{~min}$.

\section{Indirect ELISA}

VERv-specific IgM detection was performed using a previously developed Indirect ELISA [20]. The ELISA assays data are presented as the mean absorbance \pm SD. Ten single samples by group were measured in duplicate wells and optical density values (OD $450 \mathrm{~nm}$ ) of control wells were automatically subtracted from samples values.

\section{Serum neutralization tests}

Serial twofold dilutions (1:20-1:2560) of heat inactivated serum were prepared in a 96 well plate (Corning) with MEM Leibovitz medium without FBS. Diluted sera were incubated with a defined amount of infectious virus (100 $\mathrm{TCID}_{50} / 50 \mu \mathrm{L}$ ), 4 wells were used for each sample. After incubation overnight at $+4{ }^{\circ} \mathrm{C}$, the virus-serum mixture was added to a confluent E-11 cell line and incubated for 10 days at $25{ }^{\circ} \mathrm{C}$. Plates were observed every 3 days for appearance of cytopathic effects (CPE). The neutralization value of a virus is defined as the reciprocal of the highest dilution of serum that completely inhibits CPE.

\section{Real-time quantitative $P C R$}

At 0,24 and 48 h post immersion with formylated virus, 4 pools of 5 gill archs per time points per group were collected, whereas after i.p. immunization with formylated virus, 3 single samples of head kidney and gut were collected per time points and per group. Three muscle samples from control groups were sampled behind the pectoral fin. Samples were immediately placed in $1 \mathrm{~mL}$ of denaturing solution (Tripure, Roche), total RNA was isolated following the manufacturer's instructions and subsequently suspended in DEPC-treated water. For reverse transcription, the BioScript RNase $\mathrm{H}$ minus (Bioline) enzyme was used following the manufacturer's instructions. The absence of DNA contamination was checked using sea bass $\beta$-actin primers that bracketed an intron [20]. The transcripts relative to MxA and ISG12 genes were determined with an $\mathrm{Mx} 3000 \mathrm{P}^{\mathrm{TM}}$ Real-time quantitative PCR system (Stratagene) equipped with version 2.02 software, using the Brilliant SYBR Green Q-PCR Master Mix (Stratagene) following the manufacturer's instructions. ROX was used as internal passive reference dye. Specific PCR primers (Table 1) were designed for the amplification of products (ca. $200 \mathrm{bp}$ ) from the conserved region of all the analyzed genes and ribosomal $18 \mathrm{~S}$ rRNA was used as house-keeping gene. A $10 \mathrm{ng}$ of cDNA 
Table 1 Specific Real-time quantitative PCR primers

\begin{tabular}{lll}
\hline Gene & Primer sequence & EMBL accession \\
\hline 18S rRNA & FW: 5'-CCAACGAGCTGCTGACC-3' & AY831388 \\
& RW: 5'-CCGTTACCCGTGGTCC-3' & \\
B-actin & FW: 5'-ATGTACGTTGCCATCC-3' & AJ493428 \\
& RW: 5'-GAGATGCCACGCTCTC-3' & \\
MXA & FW: 5'-GTCTGGAGATCGCCTCT-3' & JN807551 \\
& RW: 5'-GTGGATCCTGATGGAGA-3' & \\
ISG12 & FW: 5'-CCTGGTACAGCTGCTGT-3' & FN665389 \\
& RW: 5'-AGCTGCTCCTGCTGACT-3' & \\
\hline
\end{tabular}

template was used in each PCR reaction. PCR conditions were as follows: $95^{\circ} \mathrm{C}$ for $10 \mathrm{~min}$, followed by 35 cycles of $95{ }^{\circ} \mathrm{C}$ for $45 \mathrm{~s}, 52^{\circ} \mathrm{C}$ for $45 \mathrm{~s}$ and $72{ }^{\circ} \mathrm{C}$ for $45 \mathrm{~s}$. Reactions were performed in triplicate for each template cDNA, which was replaced with water in all blank control reactions. Each run was terminated with a melting curve analysis, which resulted in a melting peak profile specific to the amplified target DNA. The analysis was carried out using the endpoint method option of the Mx3000P ${ }^{\mathrm{TM}}$ software, allowing the fluorescence data to be collected at the end of each extension stage of amplification. A relative quantification was performed by comparing the levels of the target transcript to the reference transcript (18S rRNA). Quantitative assessment was based on the determination of the threshold cycle $(\mathrm{Ct})$, defined as the cycle at which a statistically significant increase in fluorescence above the background signal was detected using the $\Delta \Delta \mathrm{Ct}$ method. The calibrator, defined as 1.0 value, was the average of 3 muscle samples from control fish due to the low expression of these antiviral genes in the muscle.

\section{Virological analysis \\ Virus isolation in cell culture}

Samples (cell culture supernatant and fish brains) were examined by previously described standard virological techniques [16].

Real Time RT-PCR analyses for detection of Betanodavirus RNA2 were performed using a slightly modified version of the published protocol [21]. Briefly, total RNA was extracted from $100 \mu \mathrm{L}$ of the sample using the NucleoSpin ${ }^{\circledR}$ RNA kit (Macherey-Nagel) and according to the manufacturer's instructions. Real Time RT-PCR was conducted with RotorGene Q (Qiagen), Rotor Gene 6000 (Corbett, Australia) using the OneStep RT-PCR Kit (Qiagen) following the manufacturer's recommendations, adding Random primers (Applied Biosystems) and RNase Inhibitor (Promega). Primers and probe were used at a final concentration of 0.9 and $0.75 \mu \mathrm{M}$, respectively, random primers at concentration $1 \mathrm{X}$, RNase Inhibitor at final concentration of $8 \mathrm{U} / \mu \mathrm{L}$ and thermal cycling was performed at $50{ }^{\circ} \mathrm{C}$ for $30 \mathrm{~min}$ and denaturation at $95^{\circ} \mathrm{C}$ for $10 \mathrm{~min}$ followed by 45 cycles of $95^{\circ} \mathrm{C}$ for $10 \mathrm{~s}, 54{ }^{\circ} \mathrm{C}$ for $35 \mathrm{~s}$ and $72{ }^{\circ} \mathrm{C}$ for $1 \mathrm{~s}$, with a final incubation at $40{ }^{\circ} \mathrm{C}$ for $30 \mathrm{~s}$. Data analyses were performed with the Rotor Gene 6000/RotorGene Q series software.

\section{Immunohistochemistry}

For IHC, gills from sea bass immersed with formalininactivated VERv were sampled at $48 \mathrm{~h}$ post-immersion (1 min). Gills were fixed in ice-cold Bouin's fixative for $7 \mathrm{~h}$ in Bouin's at $4{ }^{\circ} \mathrm{C}$. After embedding in paraplast, blocks were serially sectioned at a thickness of $7 \mu \mathrm{m}$ as previously described [22]. The immunohistochemical reaction was performed by $\mathrm{ABC}$-peroxidase with nickel enhancement, as previously described [23]. Serial sections were incubated with the mAb 4C3 [24] (that recognizes VERv capsid protein) diluted 1:10 in PBS 0.1 M (Sigma-Aldrich), pH 7.3 containing 5\% normal horse serum and $0.1 \%$ sodium azide, or with pAb 283 [25] (that recognizes the whole virus) diluted 1:3000 using PBS containing $5 \%$ normal goat serum and $0.1 \%$ sodium azide. Controls were carried out by omitting the primary antibody. Thereafter, sections were incubated for 60 min with biotinylated horse anti-mouse or anti rabbit IgG sera (Vector Labs., Burlingame, USA) diluted 1:1000 with PBS containing $0.1 \%$ sodium azide and $1 \%$ BSA, followed by incubation for $60 \mathrm{~min}$ with avidin-biotinylated peroxidase complex (ABC, Vectastain Elite, Vector). Following rinses and staining (diaminobenzidine and nickel enhancement), sections were dehydrated, mounted and examined under a Zeiss microscope equipped with a colour video camera (Axio Cam MRC, Arese, Milano, Italy) and a software package (KS 300 and AxioVision).

\section{Statistical analysis}

The number of fish per experimental group was calculated according to the expected mortality rate (35\%) and 0.05 as $\alpha$ error (one-side) and power $80 \%(1-\beta=0.80)$. Each fish in the study was followed over time and the event "death" was recorded and verified by Real Time RT-PCR.

The Kaplan-Meier method was used to estimate the survival function from lifetime data, which allowed to draw the survival curve for each group as a step curve and to measure the length of time the fish would survive the infection. In the graph, the $y$-axis plot indicates the cumulative probability of the surviving fish at each time [26]. To compare the different survival curves, the nonparametric Wilcoxon-Breslow-Gehan test was used for equality of survivor functions. One-sided tests with a $p<0.05$ were considered as significant. Statistical analyses for potency test were performed using the STATA 12.1 software.

Statistical analysis for immunological parameters was performed by Graph Pad Prism 6.0 software statistical 
package. The data from two differents experiments are presented as the mean \pm SD of four pools of five organs in the gills and three single samples in the head kidney and gut in Real-time quantitative PCR and ten single samples for Indirect ELISA. The statistical significance among groups for qPCR and Indirect ELISA was determined using One-way ANOVA followed by Bonferroni's multiple comparison test and the level for accepted statistical significance was $p<0.05$.

\section{Results}

\section{Virological analysis}

All three inactivation methods proved to inactivate Betanodavirus completely, with no viral growth in cell culture after 3 blind passages. The immunogens were then suitable to be used for experimental trials on animals.

No mortality was observed in fish both during and after immunization in all the treated groups. Thirty days post immunization, brains from immunized fish were collected and checked for VERv positivity by Real Time RT-PCR and virological analysis.

Positivity was found only in the live virus immersion immunized group (average ct $20.88 \pm 4.29$ ), whereas all the others gave negative results.

\section{Immunological analyses}

Anti-VERv specific IgM was detected by Indirect ELISA in serum samples after immersion and intraperitoneal immunization with the virus inactivated by different ways.

In all the samples injected intraperitoneally the presence of anti-VERv specific antibodies was detected (Figure 1). Fish immunized with formalin-inactivated VERv presented a high specific IgM production (OD $450 \mathrm{~nm}$ of ca. $0.627 \pm 0.08$ ) with respect to the control group; as well, fish immunized with BPL-inactivated VERv presented a high specific IgM production (OD $450 \mathrm{~nm}$ of ca. $0.540 \pm 0.12$ ), although a high standard deviation was observed in the latter case. Moreover, fish immunized with temperature-inactivated VERv presented a high standard deviation; some samples produced a high level of specific IgM while a lower but detectable IgM level was observed in another subjects (OD $450 \mathrm{~nm}$ of ca. $0.340 \pm 0.272$ ).

Indirect ELISA results referring to sea bass immersed in different preparations are also shown in Figure 1, where those exposed to a sub-optimal dose of live virus presented a quantity of specific IgM (OD $450 \mathrm{~nm}$ of ca. $0.445 \pm 0.1$ ) higher than that found in the formalininactivated VERv group, which has a lower antibody production. Temperature-inactivated VERv and BPLinactivated VERv immunized groups both presented a higher standard deviation compared with the formalininactivated one due to the uneven responses among examined samples. As negative controls, samples from mock-immunized fish (intraperitoneally and by immersion) showed no detectable IgM antibody, as expected.

The serum neutralization test showed neutralizing antibodies against RGNNV 283.2009 only in the formalin-inactivated VERv i.p. immunized group (average titre GMT $3.8 \pm 2.2$ ), whereas all the others showed negative results (data not shown).

Quantitative-PCR, after immersion and intraperitoneal immunization with formalin-inactivated VERv, was performed to analyze the expression of antiviral immune response genes in the gills, head kidney and gut. Transcripts levels of MxA and ISG12 genes in gills after immersion are shown in Figure 2. Results are represented as a scatter plot of pooled samples, with each dot as a pool of 5 samples at 24 and $48 \mathrm{~h}$ after immersion, using muscle as calibrator and comparing the expression with mock-immunized control. A significant modulation of MxA gene $(p<0.05)$ was observed at 24 h (Figure 2), as well as an increase at the same time for ISG12 gene (Figure 2), although not statistically significant due to the high individual variability.

The expression of genes encoding for relevant antiviral genes in head kidney and gut after intraperitoneal immunization with formalin-inactivated VERv is shown in Figure 3 as a scatter plot of individual samples, with each dot representing single samples at 24 and $48 \mathrm{~h}$ after injection, and compared to the expression in control fish. Regarding the interferon-inducible MxA gene, a significant upregulation of MxA gene $(p<0.05)$ was observed at $48 \mathrm{~h}$ in the gut (Figure 3A), whereas in head kidney a not meaningful mean increase tendency was observed at $24 \mathrm{~h}$ (Figure 3C). A significant modulation of ISG12 gene $(p<0.05)$ was observed at $48 \mathrm{~h}$ in head kidney (Figure 3D), while in the gut a significant increase at $48 \mathrm{~h}$ (Figure 3B) and at $24 \mathrm{~h}$ (Figure 3D) was registered.

\section{Immunohistochemistry}

Formalin-inactivated VERv was detected in the gills of sea bass at $48 \mathrm{~h}$ post-immersion by employing IHC. In particular, the mAb 4C3 (Figure 4A) recognised scattered cells, with a strong positive signal, distributed in the gill filaments and parallel secondary lamellae. In addition a weak reaction was homogeneously detected in the gill mucosal tissue. Notably, the control specimens (no immersion immunized animals) did not evidence any mAb 4C3 staining (Figure 4B). Differently, in immersion fish the pAb 283 (Figures 4C and D) confirmed the presence of inactivated VERv in the sea bass gills $48 \mathrm{~h}$ after the immersion, showing a strong reaction in the thin epithelium covering the secondary lamellae and in the basal 


\section{Intraperitoneal}

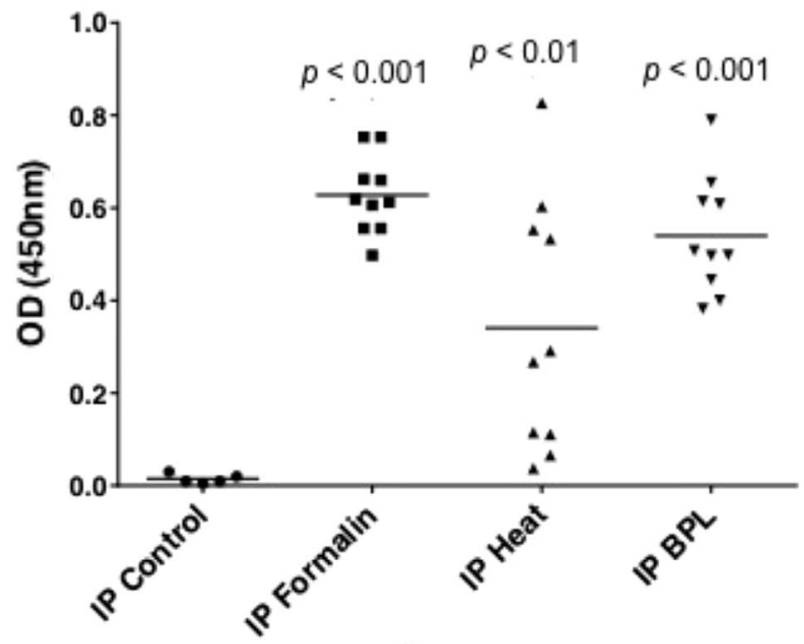

Groups

\section{Immersion}

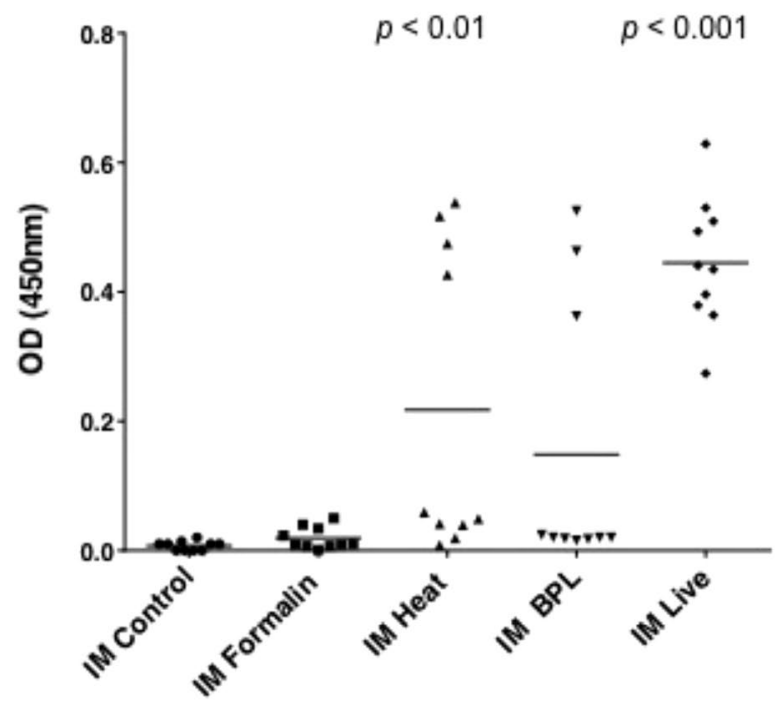

Groups

Figure 1 Detection of VERv-specific IgM after immersion and intraperitoneal immunization with Betanodavirus inactivated by different methods. Dilutions $1 / 60$ of sera from different groups collected 30 days postimmunization were tested by Indirect ELISA using as antigen $10^{6}$ $\mathrm{TCID}_{50}$ per well of viral preparation and Pab IgM (diluted 1:10000). Background values (no viral preparation added) were automatically subtracted from OD $450 \mathrm{~nm}$ values of samples.
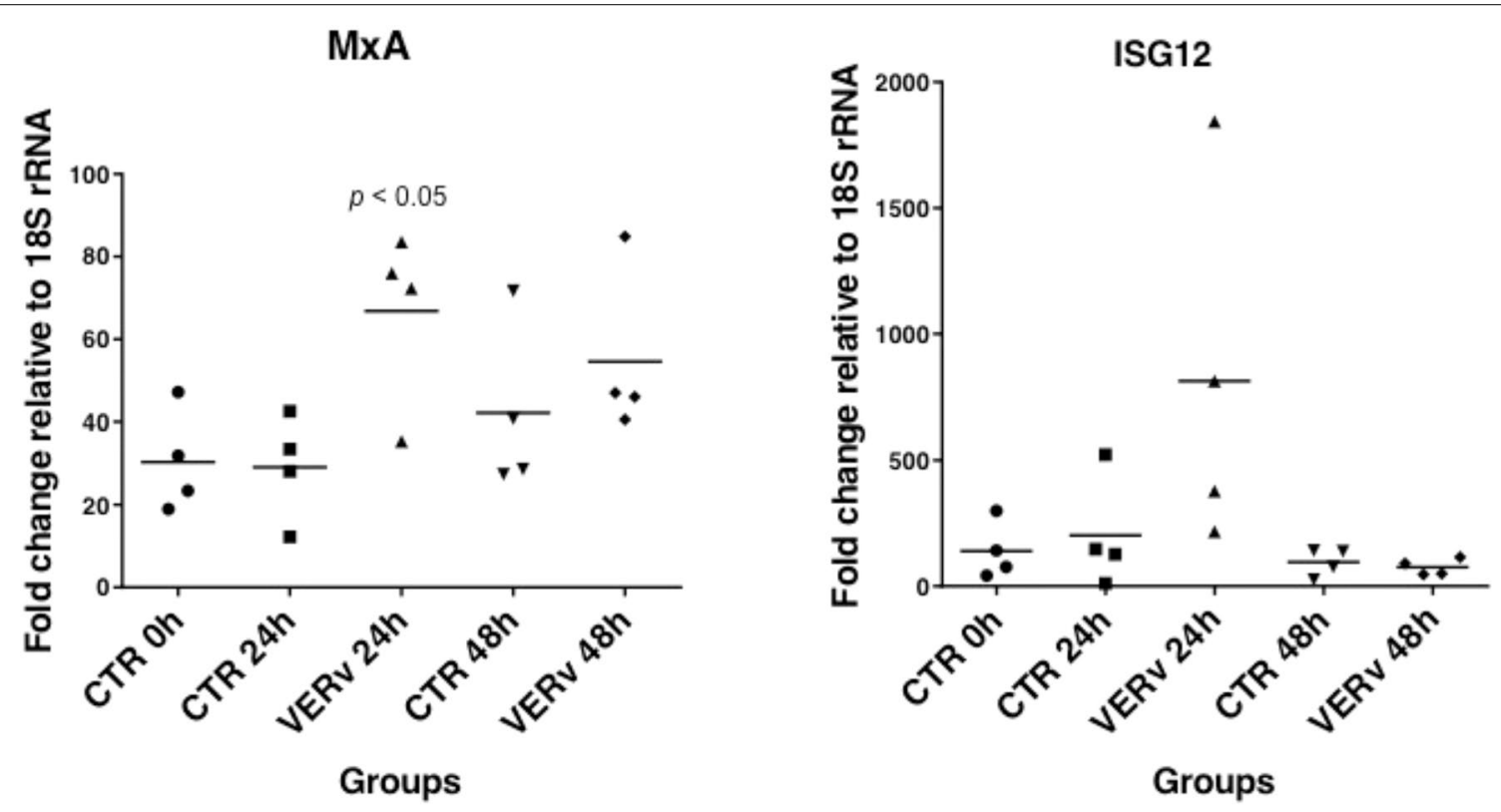

Figure 2 Real-time quantitative PCR. The expression level of genes coding for MXA and ISG 12 in gills are shown in control fish (CTR Group) and in immersed immunized fish (VERv Group) at 24 and $48 \mathrm{~h}$ post immersion with formalin-inactivated virus. The quantitative PCR amplification was performed in PCR arrays, and each point represents the mean \pm SD of four diverse pools with 5 fish each.

cells localized between the secondary lamellae on gill filaments. No reaction was found in control sections without primary antibody (Figure 4E).
Vaccine potency

The challenge was performed only on formylated groups (i.p. and immersion immunized), as described above. 


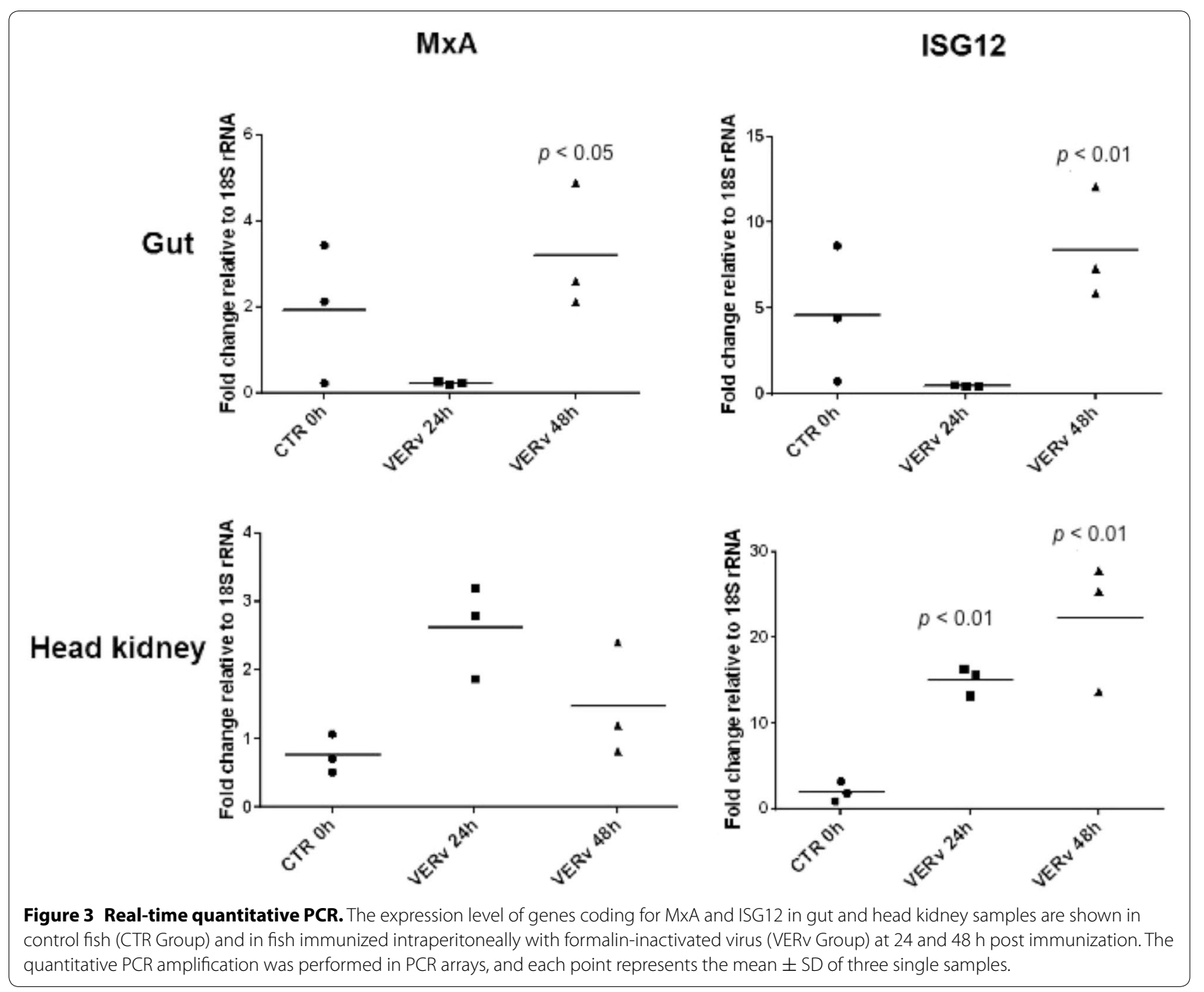

Cumulative mortality was of $12 \%$ in the i.p. immunized group and of $64 \%$ (Figure $5 \mathrm{~A}$ ) in the positive controls, with significant differences between groups $(p<0.001)$. The RPS of the i.p. immunized group was $81.9 \%$. On the other hand, immersion immunized fish showed a cumulative mortality of $50 \%$, whereas in the positive control group it turned out to be of $52 \%$ (Figure $5 \mathrm{~B}$ ), with no differences between groups $(p>0.05)$ and a RPS of $1.6 \%$.

\section{Discussion}

Betanodavirus infection is characterized by a high pathogenicity and is associated with extensive mortality in fish farms [27]. Different attempts for immunization had previously been tested by inactivating the virus with either formalin $[5,28,29]$ or binary ethylenimine (BEI) [28, 30], by the use of recombinant capsid proteins [31-33] or by DNA-based vaccines [33, 34]. Although some protection was obtained in sea bass fry by intramuscularly injecting a recombinant protein or synthetic peptides $[13,14]$, no vaccines are presently available to be used in D. Labrax (Additional file 1). In our study we tested different inactivation methods for Betanodavirus, namely by using formylation, BPL and temperature, with the aim of producing an effective antigen.

The inactivated antigen was then administered to fish through systemic (intraperitoneal) or mucosal (immersion) routes and serological results showed that formylation was the best inactivation way for the production of specific and neutralizing serum IgM after i.p. immunization. On the other hand, fish immunized i.p. with BPL and temperature-inactivated virus also showed the presence of specific serum IgM, but the high variability among individuals resulted in a poor statistical significance of data. This latter observation could be explained by assuming that the inactivation method may result in a loss of antigenicity, which in turn results in a decrease 


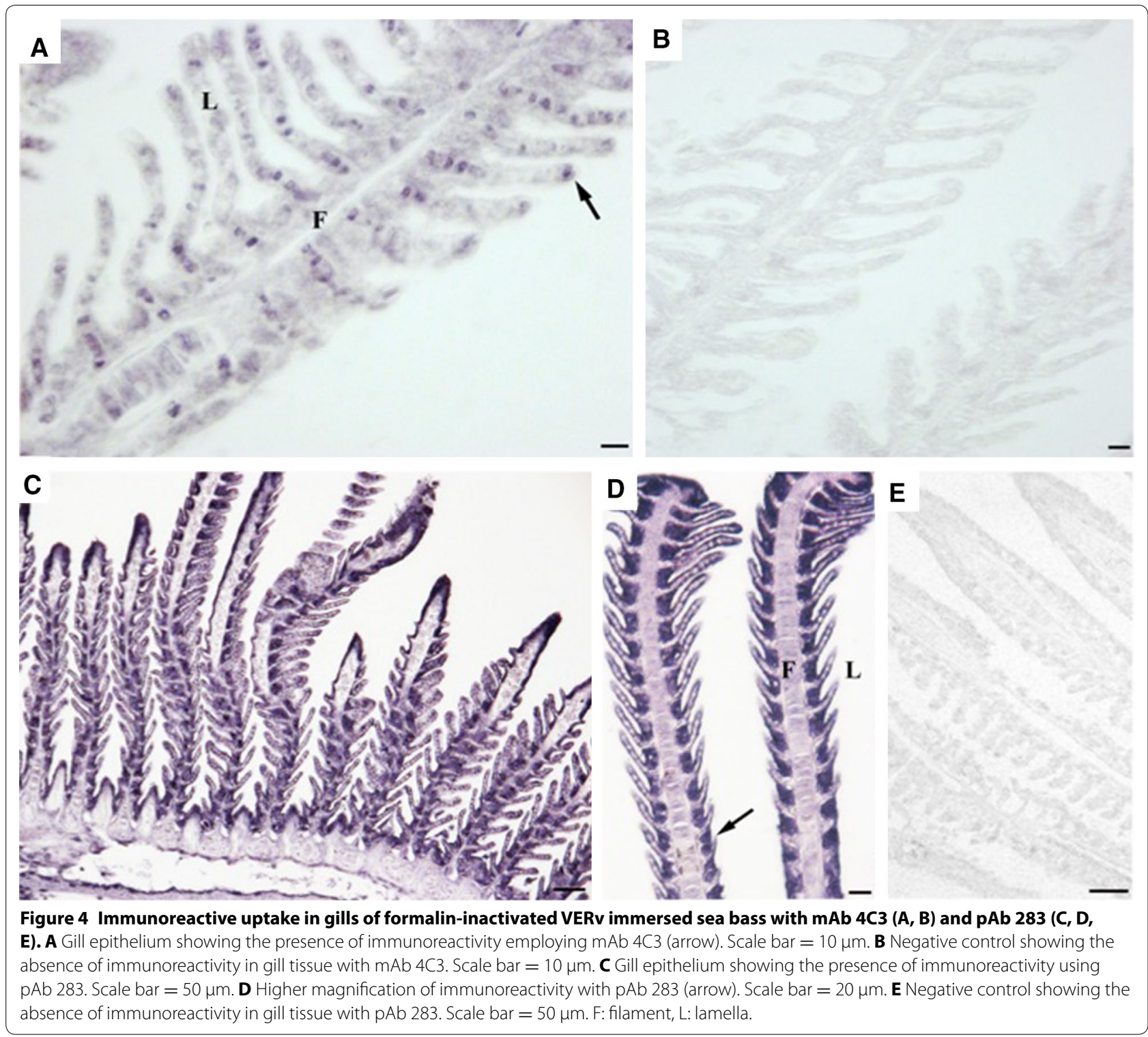

of efficient antigenic sites and, correspondingly, to the measured high standard variation in heat and BPL group. Indeed, several attempts were performed to decrease the concentration or the treatment time with formalin, BPL and temperature, all unsuccessful (data not shown) due to the resistance of Betanodavirus to chemical and physical inactivation [28, 35-38]. However, the inactivation protocols we suggested and reported in this work were able to completely inactivate the VERv.

The effectiveness of immunization with formalin-inactivated Betanodavirus administered i.p. was previously tested in other fish species. A significant specific antibody titer was measured in groupers (E. septemfasciatus) together with protection after challenge with live virus $[5,28]$. Also, a single injection of formalin-inactivated
Betanodavirus (RGNNV genotype) induced a humoral response and protection in Asian sea bass [29]. These data suggest that formylation can be a useful protocol for antigen preparation.

After having confirmed the presence of a humoral response induced by i.p. administration in sea bass, we examined the effects on the transcription of genes coding for antiviral responses. Interferon exerts its biological functions mainly through the downstream activation of Mx and ISG genes [39-42], which are both interferoninducible and known to play an active-role in antiviral immune responses [43, 44]. Mx proteins are key players of antiviral responses, triggered by interferon type I (IFN-I) in response to viral infections and have been considered the main factor in determining the resistance of 

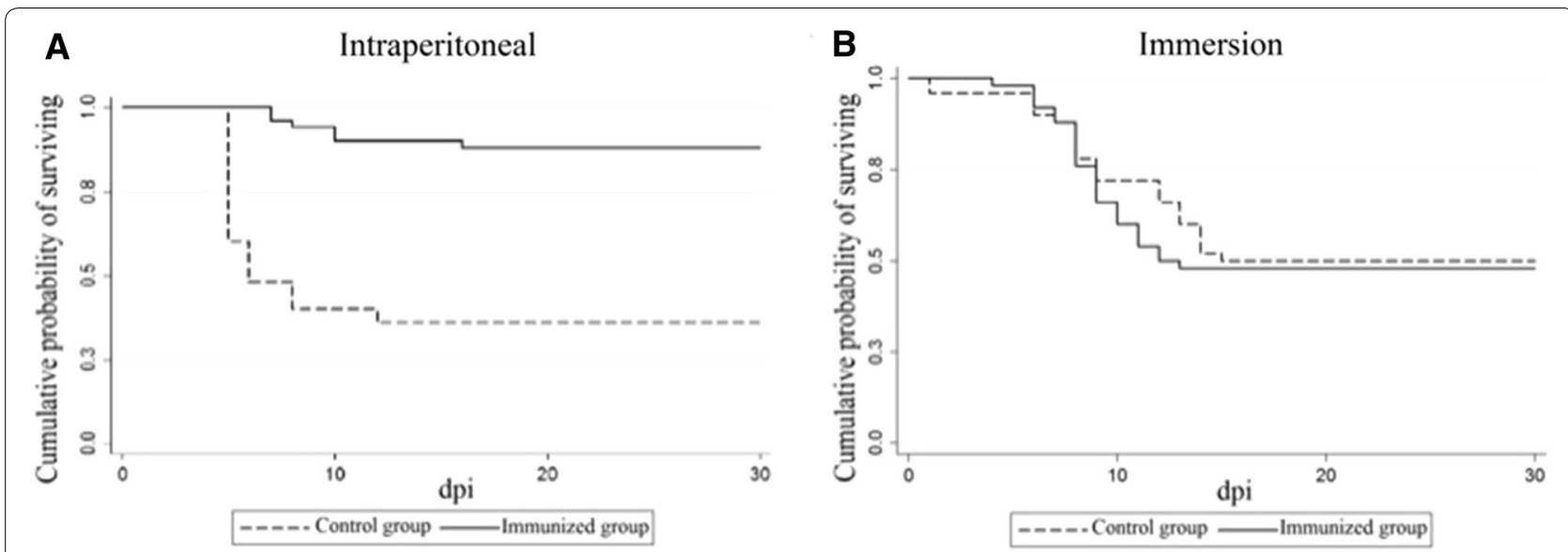

Figure 5 Cumulative survival rate of challenged sea bass previously immunized either by intraperitoneal injection or by immersion with formalin-inactivated VERv. Control group: fish mock-immunized intraperitoneally or by immersion with PBS $0.01 \mathrm{M}$; Immunized group: fish immunized (A) intraperitoneally or (B) by immersion with formalin-inactivated VERv; dpi: days post infection.

fish species to nodavirus infections. Consequently, $\mathrm{Mx}$ gene transcription can be used as an IFN-I system stimulation reporter [45]. Two different Mx genes had been identified in European sea bass, proving that the isoform MxA is particularly modulated in nodavirus-infected sea bass $[20,46]$. As previously shown [47], the ISG12 gene can also be employed in sea bass as a marker of antiviral activities, since this ISG isoform is well expressed in gills [22], and significant ISG12 gene modulation can be induced in sea bass after in vitro stimulation with virusmimicking substance poly I:C [47].

Our results showed that both MxA and ISG12 genes were significantly upregulated in head kidney and gut, thus indicating an effect of the formylated antigenic preparation. Based on promising serological and molecular results, we tested the efficacy of the immunization with formylated antigen given i.p. by challenging fish with live virus (RGNNV 283.2009). The results showed a high protection rate $(81.9 \%)$ and, therefore, a single dose of i.p.-injected, formalin-inactivated RGNNV can be considered sufficient to elicit an in vivo protection of sea bass. The potential of our formalin-inactivated viral preparation as an effective immunogen was confirmed by: (1) a measurable humoral response; (2) a modulation in the expression of antiviral genes; (3) a seroconversion assay positivity; (4) a high protection after viral challenge.

Early life stages of D. labrax are the preferred target of Betanodavirus, reaching a mortality of $100 \%$ [35, 48] and in light of this we also investigated the possibility of immunizing sea bass at a young age through mucosal routes, namely by immersion. The efficacy of immersion immunization in eliciting humoral and cell-mediated immune responses has already been described is other fish species $[49,50]$. Other interesting approaches have been explored by using inactivated VERv in immersion immunization, i.e. by employing nano-encapsulated formalin-inactivated or BEI-inactivated Betanodavirus preparations for the protection of grouper larvae (Epinephelus coioides) from NNV disease [28].

After analyzing by ELISA the results from immersion immunization with formylated nodavirus, we observed the presence of very low but still detectable specific serum IgM, which suggests that a single immersion may induce a weak humoral response in sea bass. The use of antigens encapsulated in nanoparticles could be useful to improve the delivery and the uptake also in sea bass, but this assumption needs further investigation. Furthermore, also the experimental groups immunized with BPL- and temperature-inactivated virus showed a scattered presence of specific serum IgM, resulting in a high individual variability and poor statistical significance of data, again attributable to a possible loss of antigenicity.

Being the gills directly involved in antigen uptake during immersion immunization, we analyzed the transcription of MxA and ISG12 genes at 24 and $48 \mathrm{~h}$ post immersion with formylated antigen, and we observed a significantly upregulation of these genes at $24 \mathrm{~h}$, likely suggesting a possible antiviral response in the tissue. Following immersion immunization, the Mx and ISG12 transcription resulted much higher in the gills than in the kidney or gut after i.p. immunization. We can speculate that this difference could be due to the route of antigen uptake, because gills are in direct contact with the environment and must be armed with immune defences for the protection against pathogens [51]. Importantly, the presence of viral particles was demonstrated by IHC in the gill epithelium by using antibodies against the virus capsid protein ( $\mathrm{mAb}$ 4C3) and against the whole virus (pAb 283) [25].

It should be noted that the infection with sub-optimal doses of live virus by immersion induced an effect, 
measured by the presence of significant antibody levels after 30 days (Figure 1) $[15,20]$, and this could raise the possibility of vaccinating fish with a live/attenuated virus, as already shown in a grouper species (E. septemfasciatus) $[52,53]$. However, the use of live pathogens for fish immunization raises concerns about their containment and poses risks of vertical/horizontal transmission [27]. To confirm these concerns, we observed by RT-PCR the presence of VERv in brain samples from all fish infected by sub-optimal doses of live virus (data not shown).

In summary, data obtained from immersion-immunized fish, including the lack of protection in challenge trials, suggest that this way of administration needs to be further investigated also with studies including boosting/ adjuvants.

\section{Additional file}

Additional file 1. Summary of main characteristics and results obtained with experimental vaccines against VER. The table describes the published works on attempts to produce a vaccine against VER, and corresponding references.

\begin{abstract}
Abbreviations
VER: viral encephalopathy and retinopathy; VNN: viral nervous necrosis; VERV: encephalopathy and retinopathy virus; RGNNV: redspotted grouper nervous necrosis virus; i.p.: intraperitoneal injection; BPL: $\beta$-Propiolactone; qPCR: realtime quantitative PCR; MEM-10: minimum essential medium; RPS: relative percent survival; MS-222: tricaine methanesulfonate; IHC: immunohistochemistry; pAb 283: policlonal antibody against Betanodavirus; mAb 4C3: monoclonal antibody against Betanodavirus capsid protein; BSA: bovine serum albumine; PBS: phosphate buffered saline; ELISA: enzyme-linked immunosorbent assay; SD: standard deviation; OD: optical density; FBS: fetal bovine serum; CPE: cytopathic effects; IgM: immunoglobulin M; IFN-l: interferon type I.
\end{abstract}

\section{Competing interests}

The authors declare that they have no competing interests.

\section{Authors' contributions}

$\mathrm{NNO}$ and FP conducted the experiments, collected and analyzed the data and were involved in preparation of the manuscript. CB and NNO conducted QPCR experiments. SP and NNO conducted immunohistochemistry experiments and SP was involved in the preparation of the manuscript. MT and NNO conducted statistical analysis. FB, GS and AT conceived the study, participated in its design, supervised animal welfare and were involved in manuscript preparation. All authors read and approved the final manuscript.

\section{Acknowledgements}

Authors want to thank Francesca Ellero for English review of this manuscript.

\section{Ethics statement}

The Istituto Zooprofilattico Sperimentale delle Venezie is a public health body belonging to the National Health System, authorized as user by the Italian Ministry of Health (Decree n. 78/2012-A of 13/03/2012). The animal care and use protocol adopted adheres to the Directive 2010/63/EU of the European Parliament and of the Council, implemented at national level through the Decree $n$. 26 of 4 March 2014. The experimental protocol was approved by the internal animal-welfare body (Opinion $n^{\circ} 02 / 2013$ of $4^{\text {th }}$ January 2013) and authorized by the Italian Ministry of Health (Law decree $n^{\circ} 126 / 2013$ of the $30^{\text {th }}$ May 2013).

\section{Funding}

This work was supported by the European EU FP7 Targetfish Project (20122017), Grant Agreement No. 311993.

\section{Author details}

${ }^{1}$ Department for Innovation in Biological, Agro-food and Forest Systems, University of Tuscia, Viterbo, Italy. ${ }^{2}$ Centro di Referenza Nazionale (NRL) per le patologie dei pesci, molluschi e crostacei, Istituto Zooprofilattico Sperimentale delle Venezie, Legnaro (PD), Italy. ${ }^{3}$ Epidemiologia applicata agli animali acquatici, Istituto Zooprofilattico Sperimentale delle Venezie, Legnaro (PD), Italy.

Received: 19 April 2016 Accepted: 26 July 2016

Published online: 02 September 2016

\section{References}

1. Toffolo V, Negrisolo E, Maltese C, Bovo G, Belvedere P, Colombo L, Dalla Valle L (2007) Phylogeny of betanodaviruses and molecular evolution of their RNA polymerase and coat proteins. Mol Phylogenet Evol 43:298-308

2. Vossen MT, Westerhout EM, Soderberg-Naucler C, Wiertz EJ (2002) Viral immune evasion: a masterpiece of evolution. Immunogenetics 54:527-542

3. Crane M, Hyatt A (2011) Viruses of fish: an overview of significant pathogens. Viruses 3:2025-2046

4. Terlizzi A, Tedesco P, Patarnello P (2012) Spread of pathogens from marine cage aquaculture - a potential threat for wild fish assemblages under protection regimes. Health Environ Aquacult 403-414

5. Yamashita Y, Fujita Y, Kawakami H, Nakai T (2005) The efficacy of inactivated virus vaccine against viral nervous necrosis (VNN). Fish Pathol 40:15-21

6. Vimal S, Madan N, Farook MA, Nambi KSN, Majeed SA, Rajkumar T, Venu S, Hameed AS (2014) Production of recombinant vaccine using capsid gene of nodavirus to protect Asian sea bass, Lates calcarifer (Bloch, 1790). Aquaculture 418:148-154

7. Yamashita H, Mori K, Kuroda A, Nakai T (2009) Neutralizing antibody levels for protection against Betanodavirus infection in sevenband grouper, Epinephelus septemfasciatus (Thunberg), immunized with an inactivated virus vaccine. J Fish Dis 32:767-775

8. Gomez-Casado E, Estepa A, Coll JM (2011) A comparative review on European-farmed finfish RNA viruses and their vaccines. Vaccine 29:2657-2671

9. Bovo G, Nishizawa T, Maltese C, Borghesan F, Mutinelli F, Montesi F, De Mas S (1999) Viral encephalopathy and retinopathy of farmed marine fish species in Italy. Virus Res 63:143-146

10. Le Breton A, Grisez L, Sweetman J, Ollevier F (1997) Viral nervous necrosis (VNN) associated with mass mortalities in cage-reared sea bass, Dicentrarchus labrax (L.). J Fish Dis 20:145-151

11. Yanong RPE (2010) Viral Nervous Necrosis (Betanodavirus) infections in fish. Program in fisheries and aquatic sciences. University of Florida, Gainesville, pp 2-6

12. Bovo G, Florio D (2008) Viral diseases of cultured marine fish. In: Eiras JC, Segner H, Wahli T, Kapoor BG (eds) Fish diseases. Science Publishers, Enfield, pp 202-216

13. Coeurdacier JL, Laporte F, Pepin JF (2003) Preliminary approach to find synthetic peptides from nodavirus capsid potentially protective against sea bass viral encephalopathy and retinopathy. Fish Shellfish Immunol 14:435-447

14. Thiéry R, Cozien J, Cabon J, Lamour F, Baud M, Schneemann A (2006) Induction of a protective immune response against viral nervous necrosis in the European sea bass Dicentrarchus labrax by using Betanodavirus virus-like particles. J Virol 80:10201-10207

15. Vendramin N, Toffan A, Mancin M, Cappellozza E, Panzarin V, Bovo G, Cattoli G, Capua I, Terregino C (2014) Comparative pathogenicity study of ten different Betanodavirus strains in experimentally infected European sea bass, Dicentrarchus labrax (L.). J Fish Dis 37:371-383 
16. Pascoli F, Serra M, Toson M, Pretto T, Toffan A (2016) Betanodavirus ability to infect juvenile European sea bass, Dicentrarchus labrax, at different water salinity. J Fish Dis 39:1061-1068

17. Iwamoto T, Nakai T, Mori KI, Arimoto M, Furusawa I (2000) Cloning of the fish cell line SSN-1 for piscine nodaviruses. Dis Aquat Organ 43:81-89

18. Frerichs GN, Morgan D, Hart D, Skerrow C, Roberts RJ, Onions DE (1991) Spontaneously productive C-type retrovirus infection of fish cell lines. J Gen Virol 72:2537-2539

19. Spearman-Karber $R$ (1978) Alternative methods of analysis for quantal. In: Finney D (ed) Statistical method in biological assay. Charles Griffin, London, pp 1-78

20. Scapigliati G, Buonocore F, Randelli E, Casani D, Meloni S, Zarletti G, Tiberi M, Pietretti D, Boschi I, Manchado M, Martin-Antonio B, JimenezCantizano R, Bovo G, Borghesan F, Lorenzen N, Einer-Jensen K, Adams S, Thompson K, Alonso C, Bejar J, Cano I, Borrego JJ, Alvarez MC (2010) Cellular and molecular immune responses of the sea bass (Dicentrarchus labrax) experimentally infected with Betanodavirus. Fish Shellfish Immunol 28:303-311

21. Panzarin V, Patarnello P, Mori A, Rampazzo E, Cappellozza E, Bovo G, Cattoli G (2010) Development and validation of a real-time TaqMan PCR assay for the detection of Betanodavirus in clinical specimens. Arch Virol 155:1193-1203

22. Nuñez Ortiz N, Gerdol M, Stocchi V, Marozzi C, Randelli E, Bernini C, Buonocore F, Picchietti S, Papeschi C, Sood N, Pallavicini A, Scapigliati G (2014) T cell transcripts and T cell activities in the gills of the teleost fish sea bass (Dicentrarchus labrax). Dev Comp Immunol 47:309-318

23. Abelli L, Picchietti S, Romano N, Mastrolia L, Scapigliati G (1997) Immunohistochemistry of gut-associated lymphoid tissue of the sea bass Dicentrarchus labrax (L.). Fish Shellfish Immunol 7:235-245

24. Costa JZ, Adams A, Bron JE, Thompson KD, Starkey WG, Richards RH (2007) Identification of B-cell epitopes on the Betanodavirus capsid protein. J Fish Dis 30:419-426

25. Nuñez-Ortiz N, Stocchi V, Toffan A, Pascoli F, Sood N, Buonocore F, Picchietti S, Papeschi C, Taddei AR, Thompson KD, Scapigliati G (2016) Quantitative immunoenzymatic detection of viral encephalopathy and retinopathy virus (Betanodavirus) in sea bass Dicentrarchus labrax. J Fish Dis 39:821-831

26. Van Belle G, Fisher LD, Heagerty PJ, Lumley T (2004) Biostatistics: a methodology for the health sciences. Wiley, New York

27. Chen Y-M, Wang T-Y, Chen T-Y (2014) Immunity to Betanodavirus infections of marine fish. Dev Comp Immunol 43:174-183

28. Kai Y-H, Chi S-C (2008) Efficacies of inactivated vaccines against Betanodavirus in grouper larvae (Epinephelus coioides) by bath immunization. Vaccine 26:1450-1457

29. Pakingking R Jr, Seron R, dela Pena L, Mori K, Yamashita H, Nakai T (2009) Immune responses of Asian sea bass, Lates calcarifer Bloch, against an inactivated Betanodavirus vaccine. J Fish Dis 32:457-463

30. Dos Santos N, Ireland J, Barnes AC, Home M (2004) Inactivated nodavirus vaccine. U.S. Patent; Application No. 10/545,528

31. Husgard S, Grotmol S, Hjeltnes BK, Rødseth OM, Biering E (2001) Immune response to a recombinant capsid protein of striped jack nervous necrosis virus (SJNNV) in turbot Scophthalmus maximus and Atlantic halibut Hippoglossus hippoglossus, and evaluation of a vaccine against SJNNV. Dis Aquat Organ 45:33-44

32. Lin CC, Lin JHY, Chen MS, Yang HL (2007) An oral nervous necrosis virus vaccine that induces protective immunity in larvae of grouper (Epinephelus coioides). Aquaculture 268:265-273

33. Sommerset I, Skern R, Biering E, Bleie H, Fiksdal IU, Grove S, Nerland AH (2005) Protection against Atlantic halibut nodavirus in turbot is induced by recombinant capsid protein vaccination but not following DNA vaccination. Fish Shellfish Immunol 18:13-29

34. Vimal S, Majeed SA, Nambi KSN, Madan N, Farook MA, Venkatesan C, Taju G, Venu S, Subburai R, Thirunavukkarasu AR, Hameed AS (2014) Delivery of DNA vaccine using chitosan-tripolyphosphate (CS/TPP) nanoparticles in Asian sea bass, Lates calcarifer (Bloch, 1790) for protection against nodavirus infection. Aquaculture 420:240-246
35. Munday BL, Kwang J, Moody N (2002) Betanodavirus infections of teleost fish: a review. J Fish Dis 25:127-142

36. Arimoto M, Mushiake K, Mizuta Y, Nakai T, Muroga K, Furusawa I (1992) Detection of striped jack nervous necrosis virus (SJNNV) by enzymelinked immunosorbent assay (ELISA). Fish Pathol 27:191-195

37. Liltved H, Vogelsang C, Modahl I, Dannevig BH (2006) High resistance of fish pathogenic viruses to UV irradiation and ozonated seawater. Aquacult Eng 34:72-82

38. Maltese C, Bovo G (2007) Viral encephalopathy and retinopathy. Ittiopatologia 4:93-146

39. Boudinot P, Zou J, Ota T, Buonocore F, Scapigliati G, Canapa A, Cannon J, Litman G, Hansen JD (2014) A tetrapod-like repertoire of innate immune receptors and effectors for coelacanths. J Exp Zool B Mol Dev Evol 322:415-437

40. Pallavicini A, Randelli E, Modonut M, Casani D, Scapigliati G, Buonocore F (2010) Searching for immunomodulatory sequences in sea bass (Dicentrarchus labrax L.): transcripts analysis from thymus. Fish Shellfish Immunol 29:571-578

41. Matsuyama T, Nakayasu C, Fujiwara A, Kurita J, Takano T, Ito T, Sano M (2012) Ontogeny of anti-viral hemorrhagic septicemia virus (VHSV) immunity in developing Japanese flounder. Dev Comp Immunol 37:313-322

42. Caipang CM, Hirono I, Aoki T (2003) In vitro inhibition of fish rhabdoviruses by Japanese flounder, Paralichthys olivaceus Mx. Virology 317:373-382

43. Verrier ER, Langevin C, Benmansour A, Boudinot P (2011) Early antiviral response and virus-induced genes in fish. Dev Comp Immunol 35:1204-1214

44. Collet B (2014) Innate immune responses of salmonid fish to viral infections. Dev Comp Immunol 43:160-173

45. Carballo C, Garcia-Rosado E, Borrego JJ, Alonso MC (2016) SJNNV downregulates RGNNV replication in European sea bass by the induction of the type I interferon system. Vet Res 47:6

46. Novel P, Fernández-Trujillo MA, Gallardo-Gálvez JB, Cano I, Manchado M, Buonocore F, Randelli E, Scapigliati G, Álvarez MC, Béjar J (2013) Two Mx genes identified in European sea bass (Dicentrarchus labrax) respond differently to VNNV infection. Vet Immunol Immunopathol 153:240-248

47. Pallavicini A, Randelli E, Modonut M, Casani D, Scapigliati G, Buonocore F (2010) Searching for immunomodulatory sequences in sea bass (Dicentrarchus labrax L.): transcripts analysis from thymus. Fish Shellfish Immunol 29:571-578

48. Breuil G, Mouchel O, Fauvel C, Pepin JF (2001) Sea bass Dicentrarchus labrax nervous necrosis virus isolates with distinct pathogenicity to sea bass larvae. Dis Aquat Organ 45:25-31

49. Angelidis P, Karagiannis D, Crump EM (2006) Efficacy of a Listonella anguillarum (syn. Vibrio anguillarum) vaccine for juvenile sea bass Dicentrarchus labrax. Dis Aquat Organ 71:19-24

50. Villumsen KR, Raida MK (2013) Long-lasting protection induced by bath vaccination against Aeromonas salmonicida subsp. salmonicida in Rainbow trout. Fish Shellfish Immunol 35:1649-1653

51. Phelan PE, Pressley ME, Witten PE, Mellon MT, Blake S, Kim CH (2005) Characterization of Snakehead rhabdovirus Infection in Zebrafish (Danio rerio). J Virol 79:1842-1852

52. Oh MJ, Gye HJ, Nishizawa T (2013) Assessment of the sevenband grouper Epinephelus septemfasciatus with a live nervous necrosis virus (NNV) vaccine at natural seawater temperature. Vaccine 31:2025-2027

53. Nishizawa T, Gye HJ, Takami I, Oh MJ (2012) Potentiality of a live vaccine with nervous necrosis virus (NNV) for sevenband grouper Epinephelus septemfasciatus at a low rearing temperature. Vaccine 30:1056-1063 